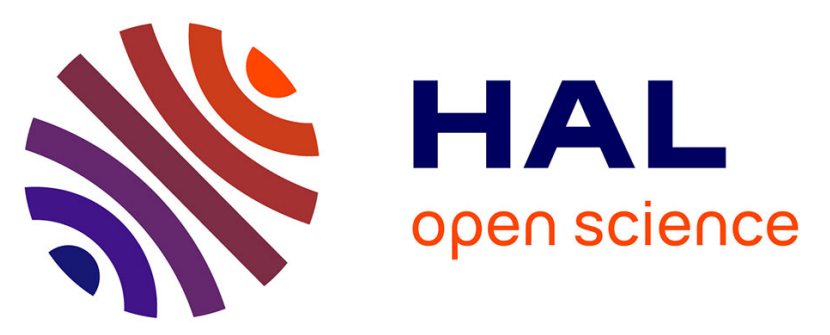

\title{
The most recent (682-792 C.E.) volcanic eruption in the Jombolok lava field, East Sayan, Central Asia triggered exodus of Mongolian pre-Chinggis Khaan tribes (778-786 C.E.)
}

Sergei G. Arzhannikov, A.V. Ivanov, Anastasia V. Arzhannikova, E.I.

Demonterova, Marc Jolivet, V.A. Buyantuev, V.A. Oskolkov, V.I. Voronin

\section{To cite this version:}

Sergei G. Arzhannikov, A.V. Ivanov, Anastasia V. Arzhannikova, E.I. Demonterova, Marc Jolivet, et al.. The most recent (682-792 C.E.) volcanic eruption in the Jombolok lava field, East Sayan, Central Asia triggered exodus of Mongolian pre-Chinggis Khaan tribes (778-786 C.E.). Journal of Asian Earth Sciences, 2016, 125, pp.87-99. 10.1016/j.jseaes.2016.05.017 . insu-01315453

\section{HAL Id: insu-01315453 \\ https://hal-insu.archives-ouvertes.fr/insu-01315453}

Submitted on 13 May 2016

HAL is a multi-disciplinary open access archive for the deposit and dissemination of scientific research documents, whether they are published or not. The documents may come from teaching and research institutions in France or abroad, or from public or private research centers.
L'archive ouverte pluridisciplinaire HAL, est destinée au dépôt et à la diffusion de documents scientifiques de niveau recherche, publiés ou non, émanant des établissements d'enseignement et de recherche français ou étrangers, des laboratoires publics ou privés. 


\section{Accepted Manuscript}

The most recent (682-792 A.D.) volcanic eruption in the Jombolok lava field, East Sayan, Central Asia triggered exodus of Mongolian pre-Chinggis Khaan tribes (778-786 A.D.)

S.G. Arzhannikov, A.V. Ivanov, A.V. Arzhannikova, E.I. Demonterova, M. Jolivet, V.A. Buyantuev, V.A. Oskolkov, V.I. Voronin

PII: S1367-9120(16)30131-6

DOI: http://dx.doi.org/10.1016/j.jseaes.2016.05.017

Reference: $\quad$ JAES 2708

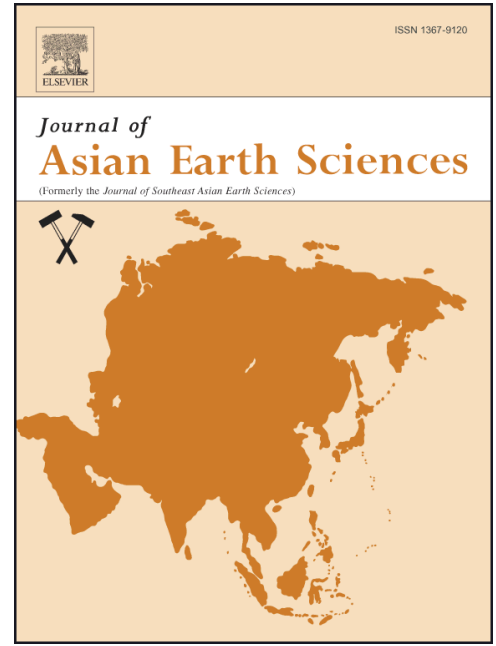

To appear in:

Journal of Asian Earth Sciences

Received Date: $\quad 15$ May 2015

Revised Date: $\quad 6$ May 2016

Accepted Date: $\quad 10$ May 2016

Please cite this article as: Arzhannikov, S.G., Ivanov, A.V., Arzhannikova, A.V., Demonterova, E.I., Jolivet, M., Buyantuev, V.A., Oskolkov, V.A., Voronin, V.I., The most recent (682-792 A.D.) volcanic eruption in the Jombolok lava field, East Sayan, Central Asia triggered exodus of Mongolian pre-Chinggis Khaan tribes (778-786 A.D.), Journal of Asian Earth Sciences (2016), doi: http://dx.doi.org/10.1016/j.jseaes.2016.05.017

This is a PDF file of an unedited manuscript that has been accepted for publication. As a service to our customers we are providing this early version of the manuscript. The manuscript will undergo copyediting, typesetting, and review of the resulting proof before it is published in its final form. Please note that during the production process errors may be discovered which could affect the content, and all legal disclaimers that apply to the journal pertain. 
The most recent (682-792 A.D.) volcanic eruption in the Jombolok lava field, East Sayan, Central Asia triggered exodus of Mongolian pre-Chinggis Khaan tribes (778-786 A.D.)

S.G. Arzhannikov*, A.V. Ivanov*, A.V. Arzhannikova*, E.I. Demonterova*, M. Jolivet**, V.A. Buyantuev***, V.A. Oskolkov***, V.I. Voronin*** $^{*}$

*Institute of the Earth’s Crust SB RAS, Irkutsk, sarzhan@crust.irk.ru

**Géosciences Rennes, UMR6118, CNRS-Université Rennes 1, Campus de Beaulieu, 35042 Rennes Cedex, France

***Siberian Institute of Plant Physiology and Biochemistry SB RAS, Irkutsk

\begin{abstract}
This study presents new data on one of the most recent (historical) volcanic eruptions in Central Asia. The Jombolok lava field located in the East Sayan Mountains (Southern Siberia) was formed during Late Pleistocene and Holocene times. At least four phases of volcanic activity have been identified and evidences associated with the last phase have been found in the upper reaches of the Khi-Gol valley and in the Oka-Jombolok basin. The volcanic activity is represented by young basaltic lava located among older lavas. Live and dead trees have been sampled in the young lava field. Nine fragments of wood have been found embedded in lavas of the latest eruption. Dendrochronological analysis, radiocarbon dating and the analysis of historical chronicles have shown that the latest eruption occurred during the period 682-792 A.D. The volcanic activity possibly triggered the migration of Mongolian tribes out of the locality known in historical chronicles as Ergune-Kun towards the Onon River, which, 400 years later, became the place of birth and rise of Chinggis Khaan.
\end{abstract}

Keywords 
Southern Siberia, Late Pleistocene and Holocene volcanic activity, Jombolok lava field Dendrochronological analysis, Historical chronicles

\section{Geographical and historical settings}

The Jombolok lava field occupies most of the Jombolok River and Khi-Gol valleys situated between the Oka Plateau and the Kropotkin Ridge in the East Sayan Mountains (Fig. 1 $\mathrm{a}, \mathrm{b}$ ). The lava field is composed of slag cones and a basaltic (hawaiite) lava flow about $75 \mathrm{~km}$ long, up to $4 \mathrm{~km}$ wide, and up to $150 \mathrm{~m}$ in thickness (Ivanov et al., 2011; Arzhannikov et al., 2014).

The Jombolok lava field has been studied for more than 230 years beginning with the visit to the Jombolok River valley of Egor Pesterev, a Russian geodesist who worked in Irkutsk in 1772-1781 (Obruchev, 1973). Thomas Witlam Atkinson (1799-1861), an English architect, artist and traveler, visited the volcanoes some years later. The first scientific description of the Jombolok lava field and Khi-Gol's volcanoes was provided by Peter Alexeevich Kropotkin (1867). In 1914 an expedition ended tragically for Sergey Pavlovich Peretolchin, a mining engineer from Irkutsk, who died under unclear circumstances. The Khi-Gol valley and the Jombolok lava field were thereafter studied repeatedly and the first geomorphological studies and descriptions of the volcanic cones and lava fields settings were conducted (Obruchev \& Lurye, 1954; Adamovich et al., 1959; Grosswald, 1965; Kiselev et al., 1979). Hypotheses were made about multiple-stage volcanic activity (Rasskazov et al., 1996; Yarmolyuk et al., 2003; Ivanov et al., 2011; Jolivet et al., 2013; Arzhannikov et al., 2014), and the role of lava tubes (Yarmolyuk et al., 2003; Ivanov et al., 2011; Arzhannikov et al., 2014) in the emplacement of the extremely long Jombolok lava field. Undoubtedly the volcanoes and recent lava post-date the last glacial period, but radioisotopic dating of basaltic lava by direct methods (such as K/Ar and ${ }^{40} \mathrm{Ar} /{ }^{39} \mathrm{Ar}$ ) was impeded by their young age and low potassium content. 
In an effort to determine the age of the most recent lava, we conducted an integrated study of the Jombolok, Oka and Khi-Gol valleys (Fig. 1 b). The study involved: the lava tube search and investigation of lava fields; satellite images and aerial photograph interpretation; sampling for radiocarbon $\left({ }^{14} \mathrm{C}\right)$ analyses and dendrochronological study of live and dead trees; analyses of medieval literary heritage. We present new data on the latest stage of volcanic eruptions within the Jombolok lava field that is considered to be the most recent known eruption in Central Asia.

\section{Geological setting}

Holocene volcanic activity within Central Asia (Fig. 2) resulted in the formation of small volcanic fields concentrated between the Baikal-Mongolia region and the eastern coast of the Sea of Japan (Siebert \& Simkin, 2002). There are also four known Holocene volcanoes in Tibet located in front of the India-Asia collision system (Siebert \& Simkin, 2002). The driving mechanism of intracontinental volcanism remains obscure, and existing models relate it to: reactivation of the asthenospheric and lithospheric mantle (e.g. Barry et al., 2007; Hunt et al., 2012); slab stagnation in the mantle transition zone (e.g. Zhao, 2004; Zorin et al., 2006; Zhao et al., 2009); lower-mantle plumes (e.g. Yarmolyuk et al., 2013).

The East Sayan Mountains are located along the southwestern margin of the Siberian Platform and border the Altai-Sayan Mountains to the northeast (Fig. 1 a). The thermochronological studies (De Grave et al., 2003; De Grave et al., 2007; De Grave et al., 2011; Jolivet et al., 2007; 2013; Buslov et al., 2008) led to the opinion that the Altai-Sayan Mountains are the northernmost reliefs associated to the intracontinental compressive deformation caused by the India-Eurasia collision (Fig. 2). Uplift initiated in the SE Sayan, during Late PliocenePleistocene (Arzhannikova et al., 2011; Jolivet et al., 2013). By Late Quaternary, the initiation of strike-slip faulting on major structures generated secondary extension within the general 
compressive stress field. It is thought that these small-scale transtensive structures allowed the emplacement of volcanics such as in the Oka region.

During the Sartanian phase of the late Pleistocene glaciation (MIS 2), the river valleys of the Oka Plateau (Oka, Sentsa, Jombolok and others) were covered by 300-400-m-thick glaciers. The edges of those glaciers are marked by terminal moraines at an absolute height of 1300-1400 m (Arzhannikov et al., 2012). The subsequent glacier retreat was associated with an intense incision into fluvioglacial deposits and the formation of a 25-30-m high terrace complex in the river valleys. The Jombolok lava field formed after this last deglaciation and represents a complex of volcanoes in the Khi-Gol valley and upper reaches of the Barun-Khadarus River associated to a system of flows of different age combined together into a long lava field in the Jombolok and Oka river valleys (Fig. 1, 3).

Dating the carbon-containing materials from ashes of the Atkinson Volcano (Fig. 3) and sub-basalt coals and fresh water mollusks from sediments of a lava-dammed lake showed that the formation of the Jombolok lava field began about 13 thousand years ago (Arzhannikov et al., 2014). Morphologically, there are at least four stages of volcanic activity (Fig. 3).

The first stage involves the formation of the Stariy and Treshina volcanoes (Fig. 3 a, c). The next stage corresponds to the closely time-spaced eruptions of the Peretolchin, Atkinson and Ostanets volcanoes (Fig. 3 a, c). The eruption events associated with these cones produced thick lavas within the Jombolok River valley, due to lava that had been channelled and flowed downstream to the Oka River valley for $75 \mathrm{~km}$. Flowing out of the narrow Jombolok valley, the basaltic lava spread towards the Oka River like a fan and dammed it (Fig. 3 b, d). Most of the outwash plain located around the periphery of the Jombolok terminal moraine was buried under basaltic lava. The initial alluvial surface had a typical micro-relief represented by a network of branched channels. The basaltic lava initially followed these micro-valleys, with some spaces between them left unfilled. 
The lava moves for long distance using the so called inflation process (Hon et al., 1994). Initially the lava is emplaced as thin sheets of fluid pahoehoe lava of a few tens of centimeters thick. Then, after formation of a solid crust upon cooling, the following magma is emplaced inside these sheets expanding them to several meters thick lava flows. If the supplied volume of magma is large enough the newly formed crust of such lava flows brakes and a new series of thin sheets of lava are formed. The remaining solidified crust of lava forms lava tubes, which are used by the next pulse of magma and so on. This process of magma emplacement, inflation and tube formation is common for basaltic eruptions and is responsible for propagation of lava long distances as for example the $\sim 1500 \mathrm{~km}$ long basaltic flows the Deccan flood basalt province (Keszthelyi et al., 2006).

The third stage includes the formation of the Kropotkin Volcano whose lava erupted in smaller volumes. These lava are found in the upper reaches of the Khi-Gol and Kadyr-Os valleys (Fig. 3, a. c). Some magma was potentially discharged through lava tubes formed previously within an older lava field.

We show below that the fourth stage occurred during historical times. The distinctive feature of the younger lava surfaces is an almost complete absence of vegetal cover, a much darker color compared to earlier generations of basalts, and a visible wave-like spread of the lava (Fig. 4 a, b). The youngest lava is most clearly defined in the Oka-Jombolok basin. It belongs to aa-type lava. The morphology of these aa-lava is also characterized by the occurrence of “islands" or kipukas of older lava with fragments of dead or sometimes living wood (Fig. 5). The kipukas of the stage 4 lava may reach 10-12 $\mathrm{m}^{2}$ though most of them are no more than 1-2 $\mathrm{m}^{2}$.

The young lava fields (stage 4 lava) are either linear-shaped or equi-dimensional. They are elongated parallel to the natural valley slope and their surface shows characteristic flow folding (Fig. 4, b). Finally, the younger lava seems to pour out from under the old lavas in a west-east direction. 
The stage 4 lava in the upper reaches of the Khi-Gol valley and the Jombolok basin were probably formed at the same time, with the outflow channels located in the area of the Kropotkin Volcano (Fig. 3 a, b). We infer that the liquid basaltic magma ( $\mathrm{t}>1100^{\circ} \mathrm{C}$, e.g. Lipman and Banks, 1987) moved toward the lower parts of the valleys for, at least, $65 \mathrm{~km}$ through tubes that were formed during the previous stages of eruption.

The flow most probably occurred at rather large depths through the tubes in the previous 150 -m thick lava. This explains the absence of stage 4 lava in the interval between the upper reaches of the Khi-Gol valley and the Oka-Jombolok basin. Lava surfacing in the basin was caused by the decrease in thickness of the older carrier flow that allowed the flowing magma to break the tubes and spread on the surface. In places, the older lava surfaces were almost entirely inundated with stage 4 lava. This scenario remains speculative and the youngest lava exposed in the Oka-Jombolok basin might have reached the surface from local eruptive channels potentially associated to the active normal faults controlling the basin. However no eruptive centers are exposed in the Oka-Jombolok basin and most of the stage 4 lava exposures are disconnected one from the other.

Ivanov et al. (2011) have compared chemical composition of the magma along the $\sim 75$ $\mathrm{km}$ Jombolok lava field and found that upon propagation from the eruption center towards the remote parts of the lava field there was a notable decrease in the $\mathrm{TiO}_{2} / \mathrm{FeO}$ ratio. However, in general the chemical composition of the samples is so similar that the chemical variations are difficult to resolve using routine analytical procedures.

\section{Dendrochronological data}

Precise and accurate dating of young basalts using the $\mathrm{K} / \mathrm{Ar}$ and $/ \mathrm{or}{ }^{40} \mathrm{Ar} /{ }^{39} \mathrm{Ar}$ methods is hampered by the low radiogenic argon content and a priori unknown initial ${ }^{40} \mathrm{Ar} /{ }^{36} \mathrm{Ar}$ ratio. Major efforts have thus been made to find wood fragments in different parts of the recent lava 
for ${ }^{14} \mathrm{C}$ dating and dendrochronology study. Sixty one fir wood samples have been taken from the kipukas of old lavas located among stage 4 lava and from the surfaces of three young lava field and adjacent areas (Fig. 6, Table 1).

In addition to the samples found on the kipukas, tree fragments have also been found buried in the lavas (Fig. 7 b, c). This last finding is of first importance since it provides the possibility of directly dating the stage 4 lava. Nine well-preserved tree fragments have been found under basaltic crusts slabs forming a linear ridge in the earlier-generation lavas, parallel to the margin of the youngest lava. The slabs, piled upon one another are up to $1 \mathrm{~m}$ high and wide and several tens of meters long. The ridge looks like a low-level, narrow fractured zone with vertical or inclined slabs. An analogous example exists in ice hummocks formed through multiple interactions of ice fields. The tree fragments located inside the ridge-zone were found at a depth of $60-70 \mathrm{~cm}$. The formation of the ridge is most probably linked to the lava flowing through the earlier tubes. When the stress produced by the lava flowing within the tube exceeded the strength of the overlying rock, a strike-slip fault developed within the tube roof hummocking of the thin lavas crust and entrapment of trees fragments (Fig. $7 \mathrm{a}, \mathrm{b}, \mathrm{c}$ ).

In addition to the preserved stem fragments, live trees were sampled from both young basalt fields and kipukas of old lava (Fig. 8 a, b). Stem discs were cut from the dead trees for dendrochronological analysis using a chain saw. Increment cores were sampled perpendicular to the longitudinal axis of living trees with a Haglof increment borer at breast height $(1.3 \mathrm{~m})$.

\section{Methodology}

The stem disks and cores were prepared for ring-width measurements using semiautomatic LINTAB II measuring system with a resolution of 10 microns under LOMO stereomicroscope at 40x magnification (Rinn, 1996). The increment cores were glued on grooved wooden base plates and polished with a belt sander along with the stem discs. The final polishing 
was performed using a scalpel with a removable blade. The 1-2 $\mathrm{cm}$ wide radial cuts from center to periphery of the stem were smoothed; the transverse surfaces of the cores taken from different positions along the stem were polished. The ring pattern was enhanced by rubbing powdered chalk onto the surface.

Standardized tree-ring chronologies (Std-chronologies) were based on the tree-ring measurements. Age trends have been estimated individually for each tree, with an age-related curve approximated by negative exponent on which tree-ring indices have been calculated. The combination of cross-correlation analysis (Holmes, 1983) with graphical method for achieving cross-dating (Douglass, 1919) has been used to determine the age of floating or standard chronology and identify missing or false rings. Cross-correlation analysis has been realized in DPL-1994 specialized software package for dendrochronological studies (Holmes, 1983), and a graphical cross-dating - in the TSAP system v3.5c with a visual comparison of variability in absolute radial growth curves $(\mathrm{t}-$ scores $>5$ with overlap more 50 years) (Cook, Kairiukstis, 1990).

The first stage involved obtaining individual Std-chronologies for both dead and alive trees. All of them have been cross-dated to identify missing rings and determine absolute dates for Std-chronologies of dead trees showing a large overlap with Std-chronologies of alive trees (Fig. 9, Table 1). Figure 9 shows a large temporal overlap between all chronologies that can serve as a reliable basis for making site chronology.

Having averaged the individual Std-chronologies obtained for all trees sampled in the investigated area, we obtained site chronology $(\mathrm{SCH})$ characterizing the dynamics of ring-width growth of conifers in the area over the last twelve centuries (Fig. 9, 10). This SCH has been tested for statistical reliability using the Arstan and COFECHA programs from the DPL-1994 software package (Holmes, 1983) (Table 2). The Inter-series correlation coefficient $(\mathrm{R}=0.393$, $99 \%$ confidence intervals) implies a provision of reliable statistics on $\mathrm{SCH}$. It is characterized by a high sensitivity coefficient $\left(\mathrm{Mean}_{\mathrm{s}}=0.57\right)$ that implies that the external factors, primarily 
climatic, have a considerable influence on tree growth variability. Tree-ring chronology is considered sensitive with Mean $_{\mathrm{s}}$ more than 0.3 (Cook, Kairiukstis, 1990).

\section{Radiocarbon dating and tree-ring chronology}

Detailed examination of the lava field surface and subsurface has revealed suitable material for dating young lava. Nine tree fragments were found at a depth of $60-70 \mathrm{~cm}$ from the surface. They were initially buried through the collapse or displacement of the lava tubes' roofs during the emplacement of the youngest lava (Fig. 7). Samples JMB-13-5, JMB-13-6 and JMB13-7 (Fig. 11a) probably belong to the same tree trunk as further ascertained by comparison of their individual tree-ring series (Fig. 11 b). Samples JMB-13-6, JMB-13-7 and JMB-13-9 (Fig. 6) have been dated using radiocarbon (Table 3). Initial sample preparation for radiocarbon dating was performed using the analytical facilities of Center for Geodynamics and Geochronology at the Institute of the Earth's Crust, Siberian Branch of the Russian Academy of Sciences.

Determination of the residual activity of the carbon samples JMB-13-7, JMB-13-9 was performed in the Laboratory of Cenozoic Geology and paleoclimatology (IGM, Novosibirsk, Russia) at the QUANTULUS-1220 (Liquid Scintillation Counters) facility. For sample JMB-136 AMS radiocarbon dating was performed in the AEON laboratory, Tucson, USA. The dates is in radiocarbon years BP (Before Present -A.D. 1950) using the half-life of 5568 years. Then these radiocarbon dates were calibrated in the program Calib Rev 7.0.4 (Stuiver and Reimer, 1993) with a confidence interval of \pm 2 sigma (Table 3 ).

The calibrated ages of samples JM-13-6, JMB-13-7 and JMB-13-7 (Table 3) indicates that one of the dated trees died between 682-868 (AMS data) or 797-1015 A.D. (LSC data) and another tree died 868-1022 A.D. (LSC data).

The analysis of the individual chronologies of living trees over the second half of the $2^{\text {nd }}$ millennium $\mathrm{AD}$ provided the standardized tree-ring chronology for this period and the 
associated floating chronology for samples from dead trees. Sample Ble2 started to grow during the calendar year 792 A.D. The age of this tree provides the upper boundary age for the volcanic activity in this area. By that time, the environmental conditions had become suitable for trees to grow on the lava fields.

\section{Historical evidences for volcanic eruptions in the Jombolok and Oka river valleys}

There are some voluminous literary sources of the history of the Mongolian and Turkic peoples for the period of pre-development and development of the Mongol State and Mongol Empire. These are the «Mongolyn Nuuts Tovchoo» (anonym.), the «Sudryn Chuulgan» (Rashid ad-Din Sinan), the «Shajrat Ul Atrak» (Abu al-Ghazi Bahadur), the «Khuraangui Altan Tovch» (anonym.), the «Altan Tovch» (Guush Luvsandanzan), the «Ertnii Mongolyn Khaadyn Undesnii Ikh Suuri Tuuj)» (anonym.?), the «Erdeniin Tovch» (Sagan Setsen), the «Bolor Erkhi (Raashpuntsag)», the «Bolor toli» (Jambadorj) and others.

These historical works contain information on the life of peoples who lived in the area of modern Mongolia and southern East Siberia from the earliest times. It is of utmost interest to study the period in the history of the Mongolian people related to their life in the locality named Ergune-Kun. The early work, «Sudryn Chuulgan» (note: we used a Russian translation «Compendium of Chronicles» (Rashid ad-Din, 1952)), and the later work, «Shajrat Ul Atrak» (note: we used a Russian translation - «Genealogical tree of the Turks and Tatars» (Abul-Ghazi, 1906)), provide similar information on the flight of the remaining Mongolian lineages to the hard-to-reach area of Ergune-Kun after their defeat in battle against the Turks. Though the period they left for Ergune-Kun and stayed therein is dated differently by Rashid ad-Din and AbulGhazi, both report valuable information on the Mongols' stay in this locality, regardless of the time of their flight. 
Rashid-ad-Din's «Sudryn Chuulgan» (Compendium of Chronicles», (Rashid ad-Din, 1952)) reports a story about a Mongolian tribe that moved once to the locality of Ergune-Kun avoiding complete extermination by Turkish tribes. This story takes place two thousand years before the chronicles were written by Rashid-ad-Din, i.e. somewhere in the $7^{\text {th }}$ century B.C. “...There is a story [once heard] from honorable, trustworthy people about some tribes which outfought the Mongols and made a great slaughter [among them] so that only two men and two women survived it. In fear of an enemy, these two families ran away to a difficult-access area surrounded by mountains and forests to which there was no way to escape except for a narrow and very hard path. There was a healthy [climate] grassy steppe within these mountains. The name of this area was Ergune-Kun. The "kun" means the "slope", and the "ergune" is "steep", i.e., "Ergune-Kun" is a "steep slope"...When the people living in these mountains and forests had multiplied and the land space [they occupied] had become small and insufficient, they held a council on the best and easiest way of leaving this wilderness gorge and narrow mountain pass. They found a place that was once an ore deposit where iron had usually been melted. Having come together, they collected much firewood and kharvars of coal, butchered and skinned 70 bulls and horses, and used [their] skins for bellows. [Thereupon] they put the firewood and coal at the foot of the slope and organized the place in such a way that the seventy bellows at a time were used to make fire burn [beneath the firewood and coal] until this [mountain] slope melted. [As a result] an immense amount of iron was dug out from the ground that left a gap for the people to pass. They all moved together out of the gorge to a wide open steppe... Some other tribes claim they also participated in blowing the fire with bellows, though the above-mentioned tribes do not admit they did [it] and argue that the Kungirat tribe... was the first to leave [the gorge], with no regard or consideration for anyone, having trampled the fireplaces of other tribes...” (author's translation from Russian version of Rashid-ad-Din, 1952).

\section{Discussion}


The Jombolok lava field consists in several different-age flows mainly formed around $13 \mathrm{ka}$ (Arzhannikov et al., 2014). However, more recent volcanic occurrences are located in the upper reaches of the Khi-Gol valley and in the Oka-Jombolok basin (Fig. 3 a, b). Several tens of outpourings of lava in the basin are located in the old lava field (Fig. $3 \mathrm{~d}$ ). The lava was emitted $65 \mathrm{~km}$ above the valley near the Kropotkin Volcano and moved through lava tubes that had formed during the previous stages of activity. Finally, the magma traveling inside the older flows broke to the surface when the flow thickness decreased to 20-30 $\mathrm{m}$ in the Oka-Jombolok basin.

The youngest lava in the Jombolok field has been indirectly dated using the radiocarbon method (Table 3). Two samples among the three dated, JMB-13-6 and JMB-13-7, were taken from the same tree (Fig. $11 \mathrm{a}, \mathrm{b})$. To determine the lower age limit for stage 4 lava, we use more reliable AMS dating result for sample JM-13-6 682-868 A.D. Given that the calibrated date is divided into two sub-periods with respective probabilities of $78 \%$ and $22 \%$ (Table 3), there are two probable periods for the death of the buried tree. Nevertheless, assuming that the tree (sample Ble2, Table 1) began to grow on recent lavas in 792 A.D, there is a good reason to believe that the most likely period for the death of the buried tree (samples JMB-13-5, JM-13-6, JMB-13-7) is 682-778 A.D. By that time, the tree might have died either naturally before arrival of the lava flow, or during the outflow of stage 4 lava. However, even though the tree had died and remained for some time on the surface of stage 1,2 lava before the outflow, it was afterwards buried under stage 4 lava. Therefore, taking the period 682-778 A.D. for granted, we fix the low age limit for the outflow of stage 4 lava.

A search for Ergune-Kun was initiated by the Russian orientalist scholars as early as the $18^{\text {th }}$ century (Bilegt, 2007). Reviewing the search for the legendary locality performed by different investigators, Banzarov (1950) and Bilegt (2007) showed a wide geographic range of possibilites. These included places near Lake Kokonor (modern China); in the inner part of the Altai Mountains; along the Argun River or in the Argun River basin; in the mountain of South 
Mongolia and by the source of the Khailar River in the Greater Khingan Range. However, some authors believe that Ergune-Kun may be found in the southern Sayan Mountains (Chagdurov, 1997, 1998) or East Tuva (Abaev, 2011).

Based on the analysis of modern toponymy and the names of the areas mentioned in the «Sudryn Chuulgan» («Compendium of Chronicles» (Rashid ad-Din, 1952)), Zoriktuev (1997) and Bilegt (2007) believed that Ergune-Kun could be located in the Argun River valley in Russia.

The most appropriate places seem to be the Argun River valley and the southern Sayan Mountains (Fig. 12). The Argun River fits this locality rather well in terms of its geographic name. However, the topography of the area does not correspond to that described by the Mongolian tribe.

A livable environment was found in the Sayan Mountains where there was a toponymic correspondence with the Mongolian names (Chagdurov, 1997). Ergune-Kun can also be translated to Erkhuu-Nekhun, where Erkhuu is the Irkut River in the Tunka basin, personified as male and Nekhun is historically personified as female (Akha) from which the name of the Oka River was derived (Fig. 12). That is, the large Irkut-Oka area is likely to correspond to the Ergune-Kun locality both topographically and toponimically (Chagdurov, 1997; Konovalov, 1999). In addition to these two areas, an area located north of Lake Khövsgöl in Mongolia (some $150 \mathrm{~km}$ south of the Oka-Jombolok basin) has also been proposed as the Ergene-Kun locality by Mongolian historian Perlee (Baldanzhapov, 1970). Mongolian-derived place names such as Mongolzhon and Mongolzhongul, directly related to lava fields are also found among the toponyms of the Jombolok River area (Fig. 3 d, 6). Chagdurov's (1997) opinion is that the ethnonym "Mongol" could only have arised in the $3^{\text {rd }}$ and $4^{\text {th }}$ centuries A.D. in the locality Ergune-Kun. Therefore, it is highly likely that some of the Mongolian tribes stayed in the valley and tributaries of the Oka River. 
The Mongolian clans left Ergune-Kun (Rashid-ad-Din, 1952) 400 years before the birth of Chinggis Khaan (Cleaves, 1982; Konovalov, 1999), i.e. around 762 A.D. An important role in the determination of time when the Mongolian lineages left Ergune-Kun is played by the family tree of Chinggis Khaan described in the «Mongolyn Nuuts Tovchoo» ("Secret History of Mongols"). In Rashid ad-Din's opinion (1952), only the Mongols and Arabs cherished the memory of their relatives.

According to the Khan's family tree, the dynasty was founded by Borte Chino who led the Mongols leaving Ergune-Kun. The source studies (Perlee, 1956; Baldanzhapov, 1970; Bilegt, 1995, 2007) made it possible to calculate the years of births of all ancestors of Chinggis Khaan.

Reviewing different-sources materials related to the assumed birthdate of Borte Chino, Bilegt (2007) reported that according to «Altan Tovch» (Guush Luvsandanzan) (Baldanzhapov, 1970; Danzan, 1973) the year of the birth of Borte Chino was 758 A.D. and according to "Bolor Toli" he was born in $\sim 610-907$ A.D. Bilegt himself (2007) considered that Borte Chino was born in 702-802 A.D., but based his studies on a date of 758 A.D.

One may suppose that 20-year-old Borte Chino could lead the Mongols leaving Ergune-Kun by 778 A.D $(758+20=778)$. Another important date is the year of the birth of Bat Tsagaan Khan, a son of Borto Chino. Bat Tsagaan Khan was born in 786 A.D., even though outside Ergune Kun (Bilegt, 2007). Therefore, the Mongolian lineages could have left ErguneKun in $\sim 778-786$ A.D.

The important aspect of this story is the cited way of migration of the tribe out of the Ergune-Kun locality by melting the mountain using a large quantity of fires. It is possible to interpret this as a geological catastrophe, dramatic in their sight, in the direct vicinity of their dwelling site and the moment they left the place was metaphorized later on as a melted mountain implying numerous sources of ignition and fire spread. An important point is that the lava flows rushed from broken lava tubes that had formed 13 thousand years ago and the volcanic activity was thus unknown from those living in the valley. 
Thus, we have four key dates: 758 A.D. - the year of the birth of Borte Chino, a founder of the khan's dynasty, who led the Mongolian lineages leaving Ergune-Kun (a melted rock mentioned therewith); 786 A.D - the year of the birth of Bat Tsagaan Khan outside ErgeneKun; 792 A.D. - the beginning of the growth of the tree (from which sample Ble 2 was taken) on stage 4 lava (Table 1); 682-778 A.D. - a time interval during which the buried tree could die. In the light of the foregoing, an important role in the determination of the upper age limit for stage 4 lava is that of the starting time of growth of the tree (sample Ble2 792 A.D.) on recent lavas. The lower age limit for the recent lavas is determined from the beginning of the period 682-778 A.D. (calibrated date) when the tree (sample JMB-13-6) probably dies.

Therefore, the volcanic activity in the southern part of the East Sayan coincides in time with the migration of the Mongols out of the locality of Ergune-Kun and may date back to 682792 A.D. making it the youngest known volcanic eruption in Central Asia. The years of births of Borte Chino and Bat Tsagaan Khan may suggest that the formation of stage 4 lava occurred during the period $778-786$ A.D.

\section{Conclusion}

Researches in the northwestern Oka Plateau (East Sayan Mountain Range, East Siberia) and Oka and Jombolok river valleys have brought new perspectives on the understanding of late Pleistocene volcanism in North Asia. The results of the detailed investigation of young lava presented in this work allowed identifying and date the latest volcanic activity in historical time within that region. The tree-ring chronology covering the period 792-2014 A.D. has been obtained for the first time for southern East Siberia. Based on AMS-dating and dendrochronological analysis of stem fragments, the latest emplacement of basaltic flows in the Jombolok River valley dates back to 682-792 A.D. The analysis of historical documents and toponyms in the investigated area allows concluding that the historical occurrence of volcanism 
coincides in time with the migration of Mongolian tribes out of the Ergune-Kun mountain area (Oka Plateau valley) 778-786A.D.

\section{Acknowledgements}

The work has been supported by the Russian Foundation for Basic Research (Project No. 13-05-00361, 16-05-00183) and the Integration and Partnership Projects of the Siberian Branch of the Russian Academy of Sciences (Nos. 69 and 77). We are grateful to Alan Gillespie, Tiffany Barry and Batbaatar Jigjidsurengiinfor helpful comments to improve the initial manuscript.

\section{References}

Abaev, N.V., 2011. On the ancestral homeland of all Turks and Mongols: "Ergenekon", "Ergune-Kun" or Tannu-Uryankhai. A new study of Tuva 1, www.tuva.asia electronic journal (in Russian).

Abul-Ghazi, 1906. Genealogical tree of the Turks and Tatars. Bulletin of the Society of Archeology, History and Ethnography at the Kazan University, 21, issues 5-6. Kazan (in Russian, translated by Sablukov, G.S.).

Angarkhaev, A.L., 1999. Unity from the depths of millennia. Buryad Unen, 15 (in Russian).

Adamovich, A.F, Grosvald, M.G. \& Zonenshain, L.P., 1959. New data on Kropotkin and Peretolchin volcanoes. Transactions of the All-Union Aerogeologic Trust, 5, 79-90 (in Russian).

Arzhannikov, S.G., Braucher, R., Jolivet, M., Arzhannikova, A.V., Vassallo, R., Chauvet, A., Bourles, D. \& Chauvet, F., 2012. History of late Pleistocene glaciations in the central Sayan-Tuva Upland (southern Siberia). Quaternary Science Reviews 49, 16-32. doi: 10.1016/j.quascirev.2012.06.005. 
Arzhannikov, S.G., Ivanov, A.V., Arzhannikova, A.V., Demonterjva, E.I., 2014. The Volcano Valley in East Sayan. Science First Hand 1, 50-67.

Arzhannikova, A., Arzhannikov, S., Jolivet, M., Vassallo, R., Chauvet, A., 2011. Pliocene to Quaternary deformation in South East Sayan (Siberia): Initiation of the Tertiary compressive phase in the southern termination of the Baikal Rift System // Journal of Asian Earth Sciences, 40, 581-594.

Baldanzhapov, P.B., 1970. Altan tobchi: the XVIII Mongolian chronicle. Ulan-Ude, 415 pp. (in Russian).

Barry, T.L., Ivanov, A.V., Rasskazov, S.V., Demonterova, E.I., Dunai, T.J., Davies, G.R., Harrison, D., 2007. Helium isotopes provide no evidence for deep mantle involvement in widespread Cenozoic volcanism across Central Asia. Lithos, 95, 415-424.

Bilegt, L., 2007. Early Mongol tribes. Ulaanbaatar, 222 pp. (in Russian).

Buslov, M.M., Kokh, D.A. \& De Grave, J., 2008. Mesozoic-Cenozoic tectonics and geodynamics of Altai, Tien Shan, and Northern Kazakhstan, from apatite fission-track data. Russian Geology and Geophysics, 9, 648-654.

Chagdurov, S. Sh., 1997. Ergune-Kun - a homeland for the Mongolian clans and tribes. The $7^{\text {th }}$ International Conference on Mongolian Studies in Ulaanbaatar, August 1997. The Russian delegation's report. Moscow, 168-172 (in Russian).

Cleaves, F.W., trans 1982. The Secret History of the Mongols. Cambridge and London. Harvard University Press., 277 pp.

Cook, E.R., Kairiukstis, L.A., 1990. Methods of dendrochronology. Application in the environmental sciences. Kluwer Academy Publishers, Dodrecht-Boston-London, 394 pp.

Danzan, L., 1973. The Altan Tobchi or Golden Summary. Moscow, 440 pp. (in Russian). 
De Grave, J., Dehandschutter, B., Van den haute, P., Buslov, M.M. \& Boven, A., 2003. Lowtemperature thermo-tectonic evolution of the Altai-Sayan Mountains, South Siberia, Russia. Geophysical Research Abstracts, 5, 11996.

De Grave, J., Buslov, M.M. \& Van den haute, P., 2007. Distant effects of India-Eurasia convergence and Mesozoic intracontinental deformation in Central Asia: Constraints from apatite fission-track thermochronology. Journal of Asian Earth Sciences, 29, 188204.

De Grave, J., Glorie, S., Zhimulev, F.I., Buslov, M.M., Elburg, M., Van den Haute P., 2011. Emplacement and exhumation of the Kuznetsk-Alatau basement (Siberia): implications for the tectonic evolution of the Central Asian Orogenic Belt and sediment supply to the Kuznetsk, Minusa and West Siberian Basins. Terra Nova, 4, 248-256.

Douglass, A.E., 1919. Climatic cycles and tree-growth: A study of the annual rings of trees in relation to climate and solar activity. Washington, $127 \mathrm{pp}$.

Grosswald, M.G., 1965. Development of relief in the Sayan-Tuva highland. Nauka, Moscow, 167 pp. (in Russian).

Holmes, R.L., 1998. Dendrochronology program library - user manual. Arizona, USA, 130 pp.

Hon, K., Kauahikua, J., Denlinger, R., MacKay, K., 1994. Emplacement and inflation of pahoehoe shet flows: Observations and measurements of active lava flows on Kilauea Volcano, Hawaii. GSA Bulletin, 106, 351-370.

Hunt, A.C., Parkinson, I.J., Harris, N.B.W., Barry, T.L., Rogers, N.W., Yondon, M., 2012. Cenozoic volcanism on the Hangai Dome, Central Mongolia: Geochemical evidence for changing melt sources and implications for mechanism of melting. Journal of Petrology, 53, 1913-1942.

Ivanov, A.V., Arzhannikov, S.G., Demonterova, E.I., Arzhannikova, A.V. \& Orlova, L.A., 2011. Jombolok Holocene volcanic field in the East Sayan Mts., Siberia, Russia: structure, 
style of eruptions, magma compositions, and radiocarbon dating. Bulletin of Volcanology, 73, 1279-1294.

Jolivet, M., Ritz, J-F., Vassallo, R., Larroque, C., Braucher, R., Todbileg, M., Chauvet, A., Sue, C., Arnaud, N., De Vicente, R., Arzhanikova, A. \& Arzhanikov, S., 2007. The Mongolian summits: An uplifted, flat, old but still preserved erosion surface. Geology, $35,871-874$.

Jolivet, M., Arzhannikov, S., Arzhannikova, A., Chauvet, A., Vassallo, R., Braucher, R. Geomorphic Mesozoic and Cenozoic evolution in the Oka-Jombolok region (East Sayan ranges, Siberia). Journal of Asian Earth Sciences, 62, 117-133.

Keszthelyi, L., Self, S., and Thordarson, T., 2006, Flood lavas on Earth, Io and Mars. Journal of the Geological Society, London, 163, 253-264. doi: 10.1144/0016-764904-503.

Kiselev, A.I., Medvedev, M.E. \& Golovko, G.A., 1979. Volcanism of the Baikal rift zone and deep-seated magma formation problems. Moscow, 164 pp. (in Russian).

Konovalov, P.B., 1999. Aspects of ethnic history of Central Asia. Ulan-Ude, 214 pp. (in Russian).

Kropotkin, P.A., 1867. A trip to the Oka guard post. Memoirs of the Russian Geographical Society, Siberian Division. Irkutsk, book 9-10. (in Russian).

Lipman, P.W., Banks, N.G., 1987. Aa-flow dynamics, Mauna Loa 1984. Volcanism in Hawaii. $1350,1527-1567$.

Obruchev, S.V., \& Lurye, M.L., 1954. Kropotkin and Peretolchin volcanoes in East Sayan. Transactions of the Laboratory of Volcanology, 8, 210-225 (in Russian).

Obruchev, S.V., 1973. Mystery stories. Moscow, 112 pp. (in Russian).

Rasskazov, S.V., Kunk, M.J., Lur, D.F., Bowring, S.A., Brandt, I.S., Brandt, S.B., Ivanov, A.V., 1996. Episodes eruptions and variations in the composition of Quaternary lavas of the Baikal Rift System // Geology and Geophysics, 6, 3-15. 
Rashid-ad-Din, 1952. Compendium of Chronicles. Vol. 1-3. Moscow-Leningrad, 995 pp. (in Russian, translated by Khetagurov, L.A.).

Rinn, F., 1996. TSAP version 3.5. Reference manual. Computer program for tree-ring analysis and presentation. Heidelberg, $264 \mathrm{pp}$.

Siebert, L. \& Simkin, T., 2002. Volcanoes of the world: an illustrated catalog of Holocene volcanoes and their eruptions. Smithsonian Institution, Global Volcanism Program Digital Information Series, GVP-3, (http://www.volcano.si.edu/gvp/world/).

Stuiver, M., and Reimer, P.J., 1993. Radiocarbon, 35, 215-230.

Yarmolyuk, V.V., Kuzmin, M.I., Vorontsov, A.A. \& Khomutova, M.Yu., 2013. West Pacifictype convergent boundaries: Role in the crust growth history of the Central-Asian orogen. Journal of Asian Earth Sciences, 62, 67-78.

Yarmolyuk, V.V., Nikiforov, A.V. \& Ivanov, V.G., 2003. The structure, composition, sources and mechanism of Jombolok valley lava flows (Holocene, South-Baikal volcanic area). -Vulkanologiya i Seismologiya, 5, 41-59 (in Russian).

Yarmolyuk, V.V., Kudryashova, E.A., Kozlovskyi, A.M. \& Savatenkov, V.M., 2011. Late Cenozoic province in Central and Eastern Asia. Petrology, 19, 4, 327-347.

Zhao, D., 2004. Global tomographic images of mantle plumes and subducting slabs: insight into deep Earth dynamics. Phys Earth Planet Inter, 146, 3-35.

Zhao, D., Tian, Y., Lei, J., Liu, L., Zheng, S., 2009. Seismic image and origin of the Changbai intraplate volcano in East Asia: role of big mantle wedge above the stagnant Pacific slab. Phys Earth Planet Inter, 173, 197-206.

Zorin, Yu.A., Turutanov, E.Kh., Kozhevnikov, V.M., Rasskazov, S.V., Ivanov, A.V. (2006) The nature of Cenozoic upper mantle plumes in East Siberia (Russia) and Central Mongolia. Rus Geol Geophys, 47, 1046-1059. 
Table 1.

Register of samples and lifespan of live and dead trees.

\begin{tabular}{|c|c|c|c|c|c|}
\hline $\begin{array}{l}\text { Site } 1 \\
\text { Code } \\
\text { samples }\end{array}$ & Lifespan & $\begin{array}{l}\text { Site } 2 \\
\text { Code } \\
\text { samples }\end{array}$ & Lifespan & $\begin{array}{l}\text { Site } 3 \\
\text { Code } \\
\text { samples }\end{array}$ & Lifespan \\
\hline Jo1e3v & $1576-2012 \mathrm{D}$ & Lp2e1 & $1778-1994 \mathrm{D}$ & Ble2 & $792-1471 \mathrm{D}$ \\
\hline Jo $1 \mathrm{e} 4 \mathrm{~b}$ & $1115-1825 \mathrm{D}$ & Lp2e2 & $1693-1973 \mathrm{D}$ & Ble3 & $1583-1942 \mathrm{D}$ \\
\hline Jo1e $5 \mathrm{v}$ & $1496-2013 \mathrm{~L}$ & Lp2e2a & $1458-1744 \mathrm{D}$ & Ble4 & $1255-1834 \mathrm{D}$ \\
\hline Jo1e7v & $1568-2013 \mathrm{~L}$ & Lp2e3 & $1615-1792 \mathrm{D}$ & Ble 5 & $1285-1790 \mathrm{D}$ \\
\hline Jo1e8v & $1502-2007 \mathrm{D}$ & Lp2e4 & $1793-1920 \mathrm{D}$ & Ble 6 & $1520-1906 \mathrm{D}$ \\
\hline Jo1e11n & $1549-2013 \mathrm{~L}$ & Lp2e5a & $1606-2014 \mathrm{~L}$ & Ble7 & $1432-1737 \mathrm{D}$ \\
\hline Jo1e12v & $1498-1947 \mathrm{D}$ & Lp2e6 & $1402-1768 \mathrm{D}$ & Ble8 & $1499-1867 \mathrm{D}$ \\
\hline $\mathrm{Jmb} 1 \mathrm{e} 9 \mathrm{v}$ & $1851-2013 \mathrm{~L}$ & Lp2e9a & $1649-2014 \mathrm{~L}$ & Ble9 & $1589-1957 \mathrm{D}$ \\
\hline Jmb 1-2b & $1637-2012 \mathrm{D}$ & Lp2e10 & $1632-1954 \mathrm{D}$ & Ble10 & $1216-1616 \mathrm{D}$ \\
\hline $\mathrm{Jmb} 1-5 \mathrm{v}$ & $1496-2013 \mathrm{~L}$ & Lp2e11 & $1574-2005 \mathrm{D}$ & Ble11 & $1544-1969 \mathrm{D}$ \\
\hline *J1el1b-a & $1183-1778 \mathrm{D}$ & Lp2e12 & $1590-1996 \mathrm{D}$ & Ble12 & $1571-1948 \mathrm{D}$ \\
\hline \multirow[t]{12}{*}{$* \mathrm{~J} 1 \mathrm{el1b}$} & $1275-1817 \mathrm{D}$ & Lp2e13b & $1303-1973 \mathrm{D}$ & Ble13 & $1573-1799 \mathrm{D}$ \\
\hline & & Lp2e15 & $1479-1816 \mathrm{D}$ & Ble16 & $1568-1850 \mathrm{D}$ \\
\hline & & Lp2e16 & $1598-1984 \mathrm{D}$ & Ble16a & $1446-1615 \mathrm{D}$ \\
\hline & & Lp2e20 & $1481-1804 \mathrm{D}$ & Ble16c & $1022-1460 \mathrm{D}$ \\
\hline & & Lp2e22 & $1470-1831 \mathrm{D}$ & Ble17 & $1290-1841 \mathrm{D}$ \\
\hline & & Jo2el & $1646-2012 \mathrm{D}$ & Ble21 & $1522-2014 \mathrm{~L}$ \\
\hline & & Lp1 e1 & $1439-1861 \mathrm{D}$ & Ble 22 & $1409-1862 \mathrm{D}$ \\
\hline & & Lp1e2 & $1515-1894 \mathrm{D}$ & Ble23 & $1567-2014 \mathrm{~L}$ \\
\hline & & Jmb 2-1 & $1723-1974 \mathrm{D}$ & Ble25 & $1823-2014 \mathrm{~L}$ \\
\hline & & *Jmb 2-2 & $1608-1827 \mathrm{D}$ & Serg1 & $1597-2012 \mathrm{~L}$ \\
\hline & & $* J m b 2-2 a$ & $1608-1851 \mathrm{D}$ & Serg2 & $1568-2012 \mathrm{~L}$ \\
\hline & & Jmb 2-3 & $1704-1996 \mathrm{D}$ & Jo 3eljiv & $1640-2013 \mathrm{~L}$ \\
\hline 8 & & Jmb 2-4 & $1722-2001 \mathrm{D}$ & Jmb 3-e3 & $1615-2013 \mathrm{~L}$ \\
\hline & & & & Jmb3e & $1641-2013 \mathrm{~L}$ \\
\hline
\end{tabular}

Mean serial correlation is 0.393 within span 375 years. The marked* samples belong to the one tree trunk.

L - living tree; D - dead tree. All samples are Picea obovata. 
Table 2.

Tree ring statistics of spruce chronology from the lava fields.

\begin{tabular}{|c|c|c|c|c|c|c|c|c|c|c|}
\hline \multirow[t]{2}{*}{ Time span } & \multirow[t]{2}{*}{ MS } & \multirow[t]{2}{*}{ SNR } & \multirow[t]{2}{*}{$\sigma, \%$} & \multicolumn{2}{|l|}{$\mathrm{AC}$} & \multirow[t]{2}{*}{$\mathrm{R}$} & \multicolumn{3}{|c|}{$\begin{array}{l}\text { Variance explained by } \\
\text { principal components, } \\
\%\end{array}$} & $\sum_{\%} \mathrm{PC}_{1-3}$, \\
\hline & & & & Or1 & Or2 & & $\mathrm{PC1}$ & $\mathrm{PC2}$ & PC3 & \\
\hline $792-2014$ & 0,63 & 7,2 & 0,32 & 0,36 & 0,15 & 0.39 & 52 & 27 & 9 & \\
\hline
\end{tabular}

MS - mean sensitivity, SNR - signal to noise ratio, $\sigma$ - variance, $\mathrm{AC}$ - autocorrelation $(\mathrm{OR} 1,2$ -

first- and second-order), $\mathrm{R}$-mean inter-series correlation, $\mathrm{PC}$ - principal component, $\Sigma \mathrm{PC} 1-3-\mathrm{a}$ sum of three principal components. The mean inter-series correlation is the average of the pairwise correlations (Pearson's $r$ coefficients) computed between individual tree chronologies over the maximum common time period.

Table 3.

Radiocarbon dates of the buried woods.

\begin{tabular}{|c|c|c|c|c|c|c|}
\hline $\begin{array}{c}\text { Laboratory } \\
\text { code }\end{array}$ & $\begin{array}{c}\text { Sample } \\
\text { code }\end{array}$ & $\begin{array}{c}\text { Materia } \\
1\end{array}$ & Method & $\begin{array}{c}{ }^{14} \text { C age } \\
\text { Year BP }\end{array}$ & $\begin{array}{c}\text { Calibrated } \\
\text { age, year } \\
\text { BP }\end{array}$ & $\begin{array}{c}\text { Calibrated age, } \\
\text { year AD }\end{array}$ \\
\hline Aeon 1628 & JMB-13-6 & wood & AMS & $1245 \pm 25$ & $1082-1268$ & $\begin{array}{c}682-778(78 \%) \\
790-868(22 \%)\end{array}$ \\
\hline SOAN-9159 & JMB-13-7 & wood & LSC & $1120 \pm 55$ & $935-1153$ & $797-1015(94 \%)$ \\
\hline SOAN-9160 & JMB-13-9 & wood & LSC & $1095 \pm 40$ & $928-1082$ & $868-1022(98 \%)$ \\
\hline
\end{tabular}

AMS analysis is by AEON Laboratory (Radiocarbon Dating Service), Tucson, USA (www.aeonlaboratories.com).

LSC analysis (Liquid Scintillation Counters) performed at IGM SB RAS, Novosibirsk, Russia at the QUANTULUS-1220 facility.

Radiocarbon dates were calibrated in the program Calib Rev 7.0.4 (Stuiver and Reimer, 1993). 

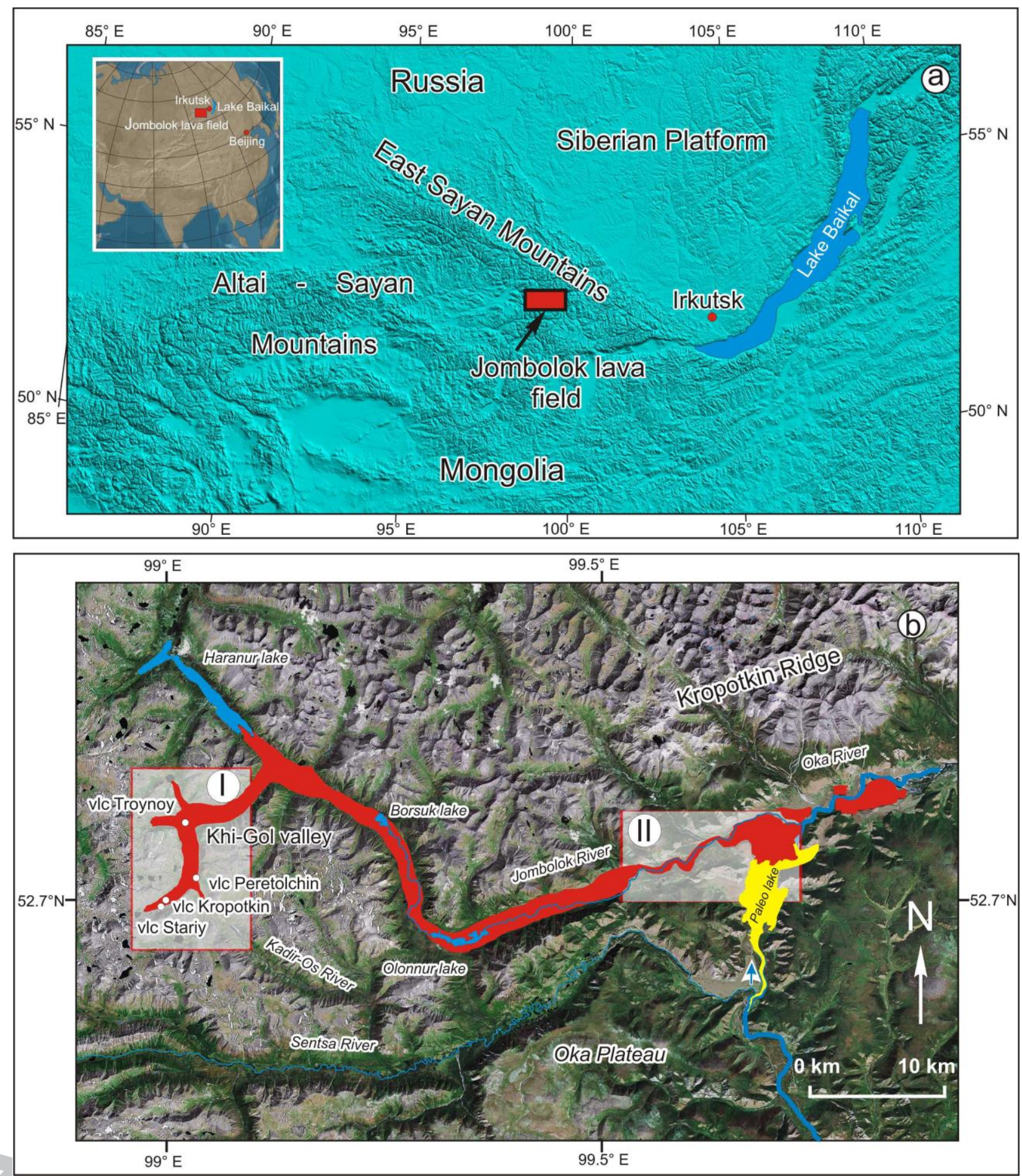

Fig. 1. (a) Overview map showing the position of the study area in Central Asia. (b) The Jombolok volcanic field. Lava is shown in red. Lava-dammed Oka paleolake is coloured yellow. Transparent rectangle with red boundaries marks studied areas (Fig. 3a and 3b): I - Khi-Gol valley; II - Oka-Jombolok area; vlc - volcano. 


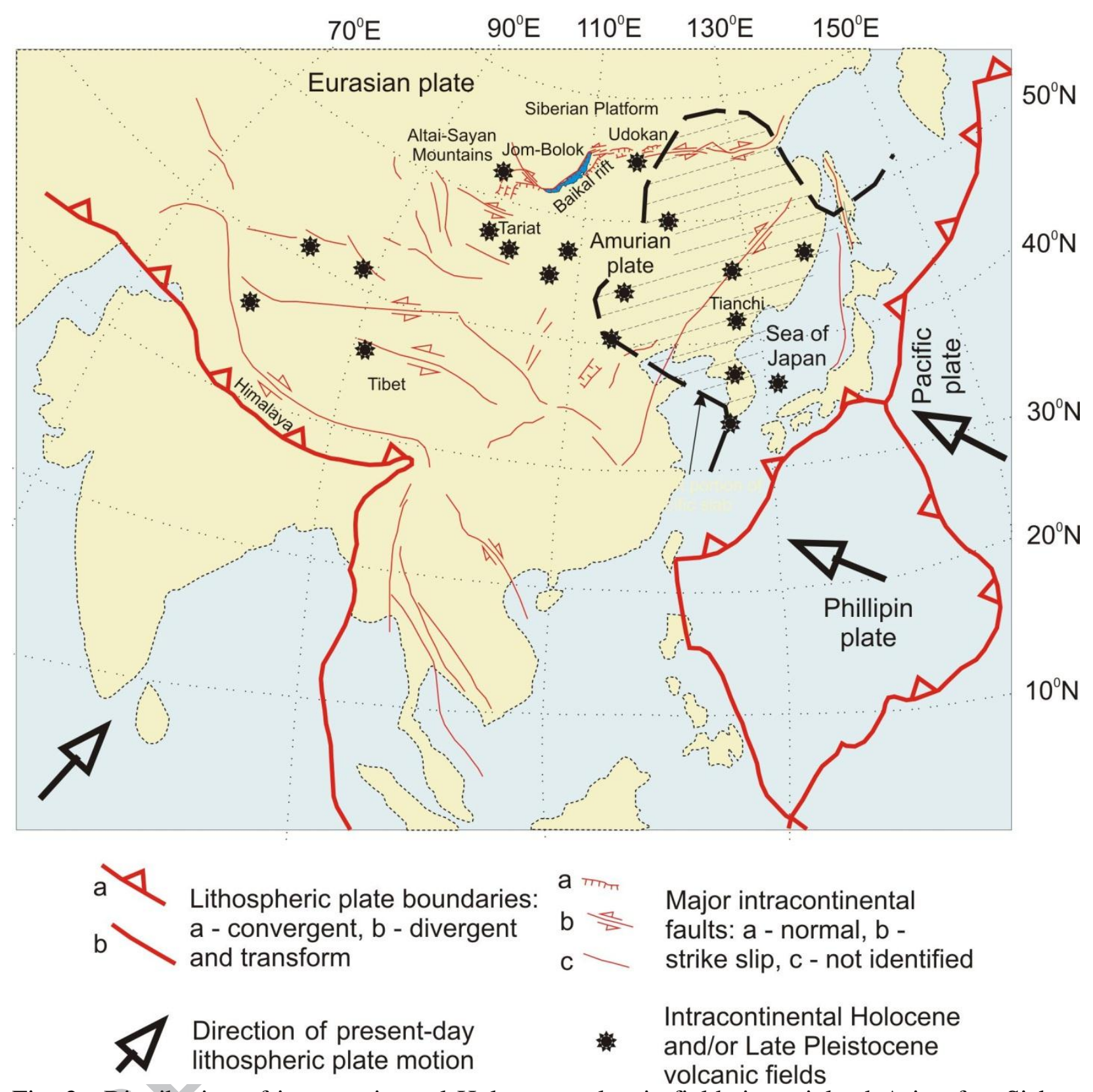

Fig. 2. Distribution of intracontinental Holocene volcanic fields in mainland Asia after Siebert and Simkin (2002) with minor modifications for the Baikal region and Mongolia. Hatched field outlined with dashed black line shows surface projection of the Pacific slab stagnant in the mantle transition zone after Zhao (2004) and Zorin et al. (2006). 

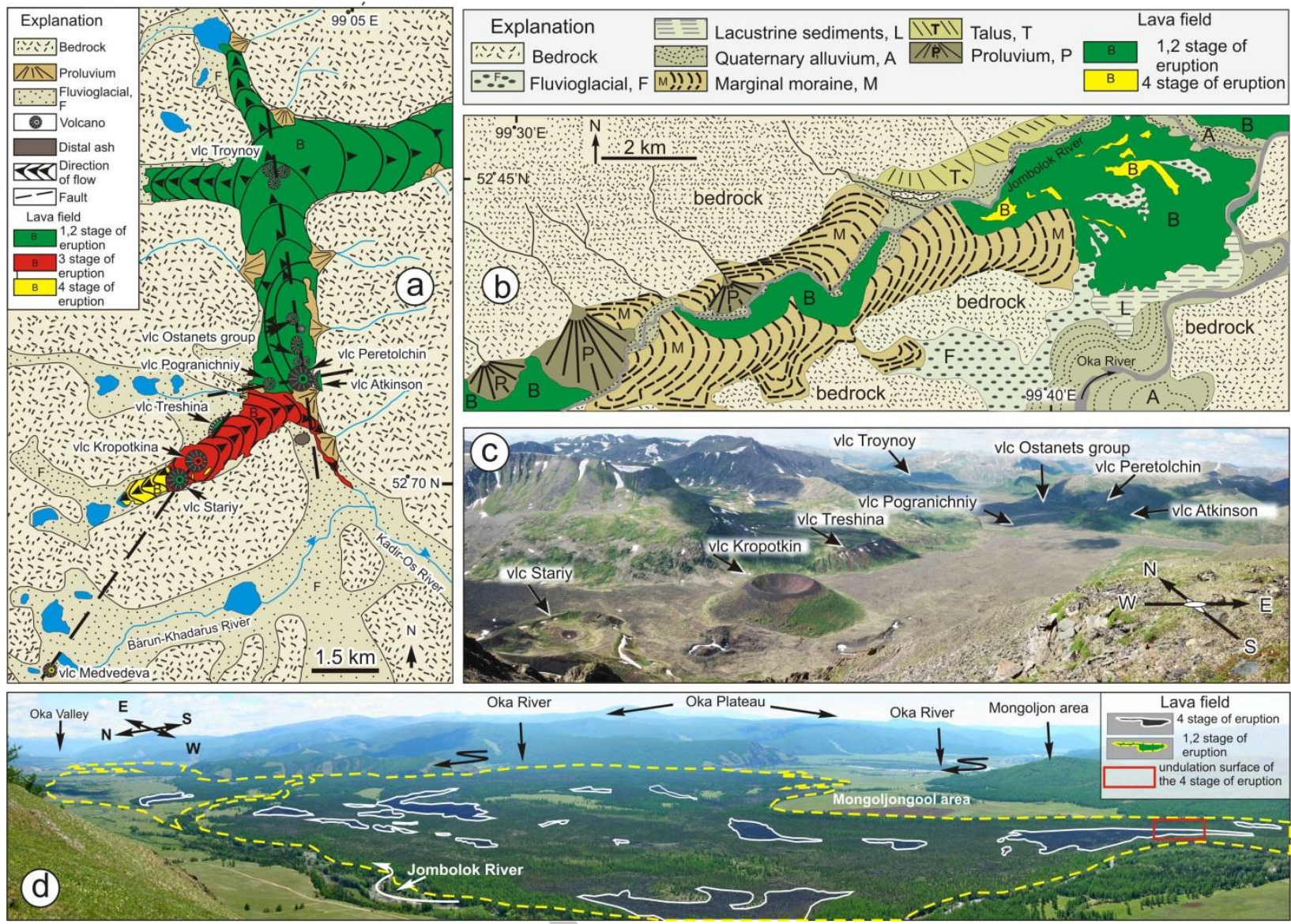

Fig. 3. Distribution pattern of lava fields and lava outpouring sources of different generations in the Khi-Gol valley $(a, c)$ and Oka-Jombolok basin (b, d); a view of the Khi-Gol volcano valley (c); a view of the Oka-Jombolok basin (d); vlc - volcano. 

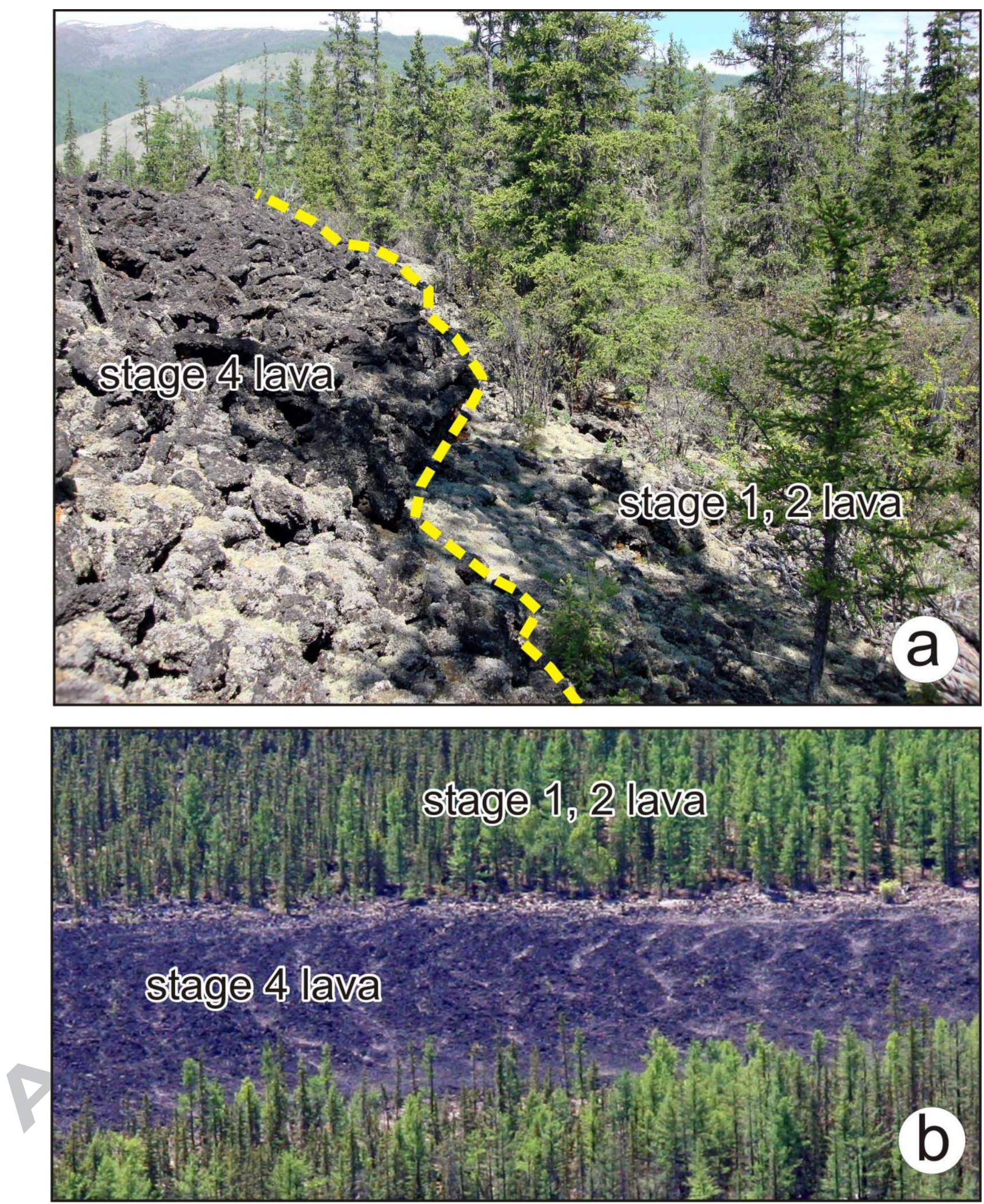

Fig. 4. (a) Stage 4 lava morphology, the dashed yellow line shows the contact between the two lava generations; (b) undulating surface of the stage 4 lava among vegetated old lava. This area is marked with a red rectangle in Figure $3 \mathrm{~d}$. 


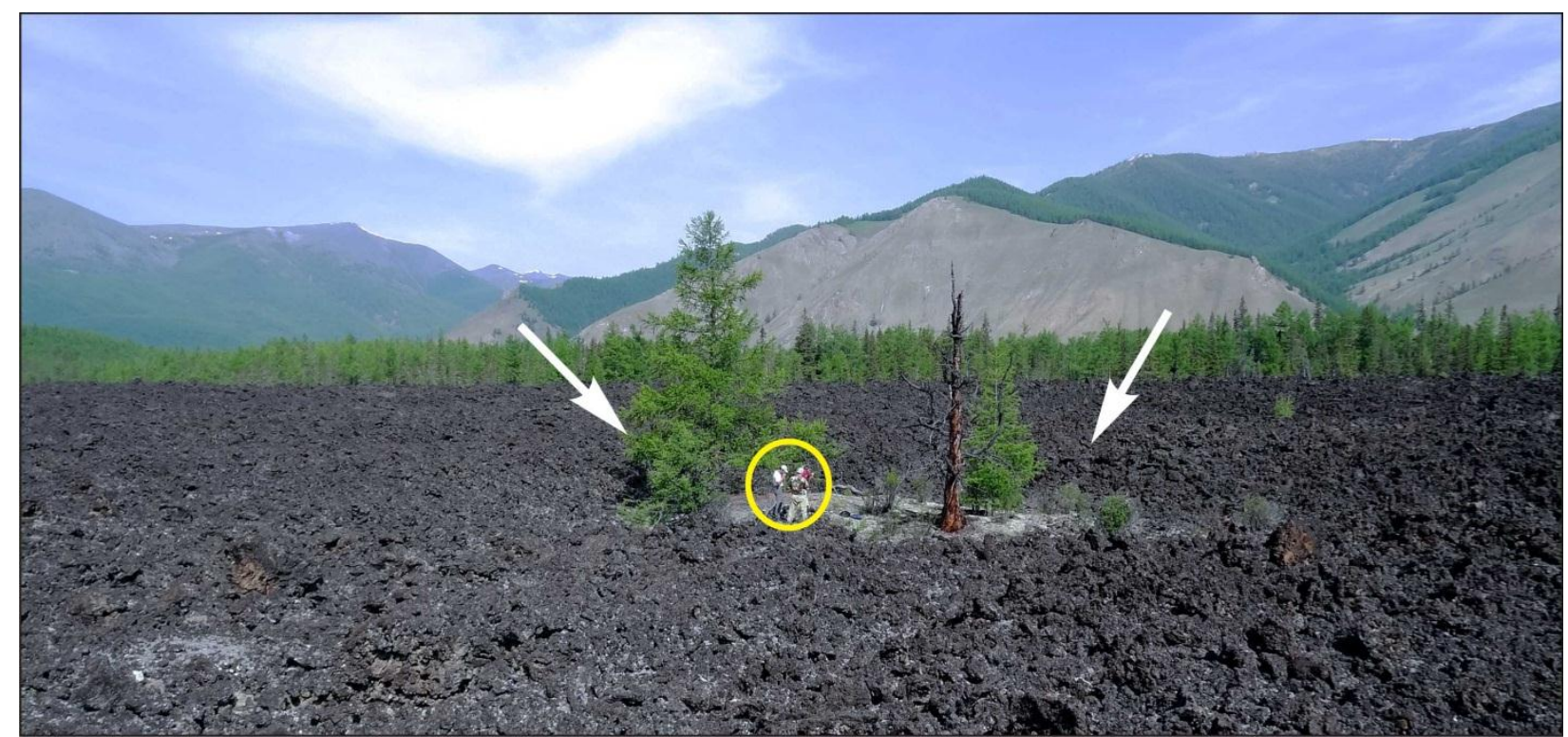

Fig. 5. A kipuka covered by woody vegetation among stage 4 lava. People in the yellow circle are for the scale.

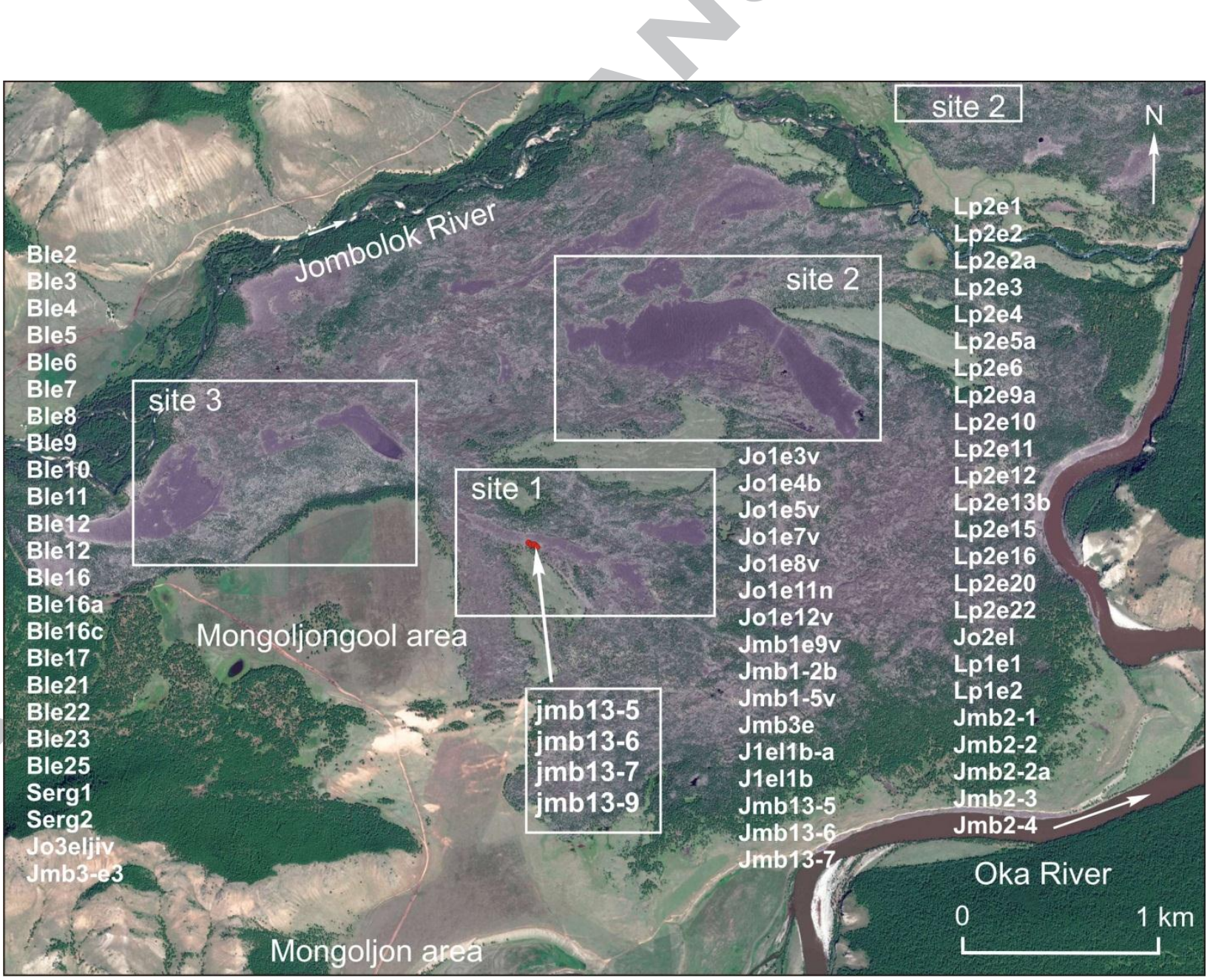

Fig.6. Oka-Jombolok basin. Stage 4 lava (dark areas) is situated among stages 1, 2 lava generations. White rectangles mark the fields of sampling of the dead and live trees. Red circles show the place of sampling of buried trees. 

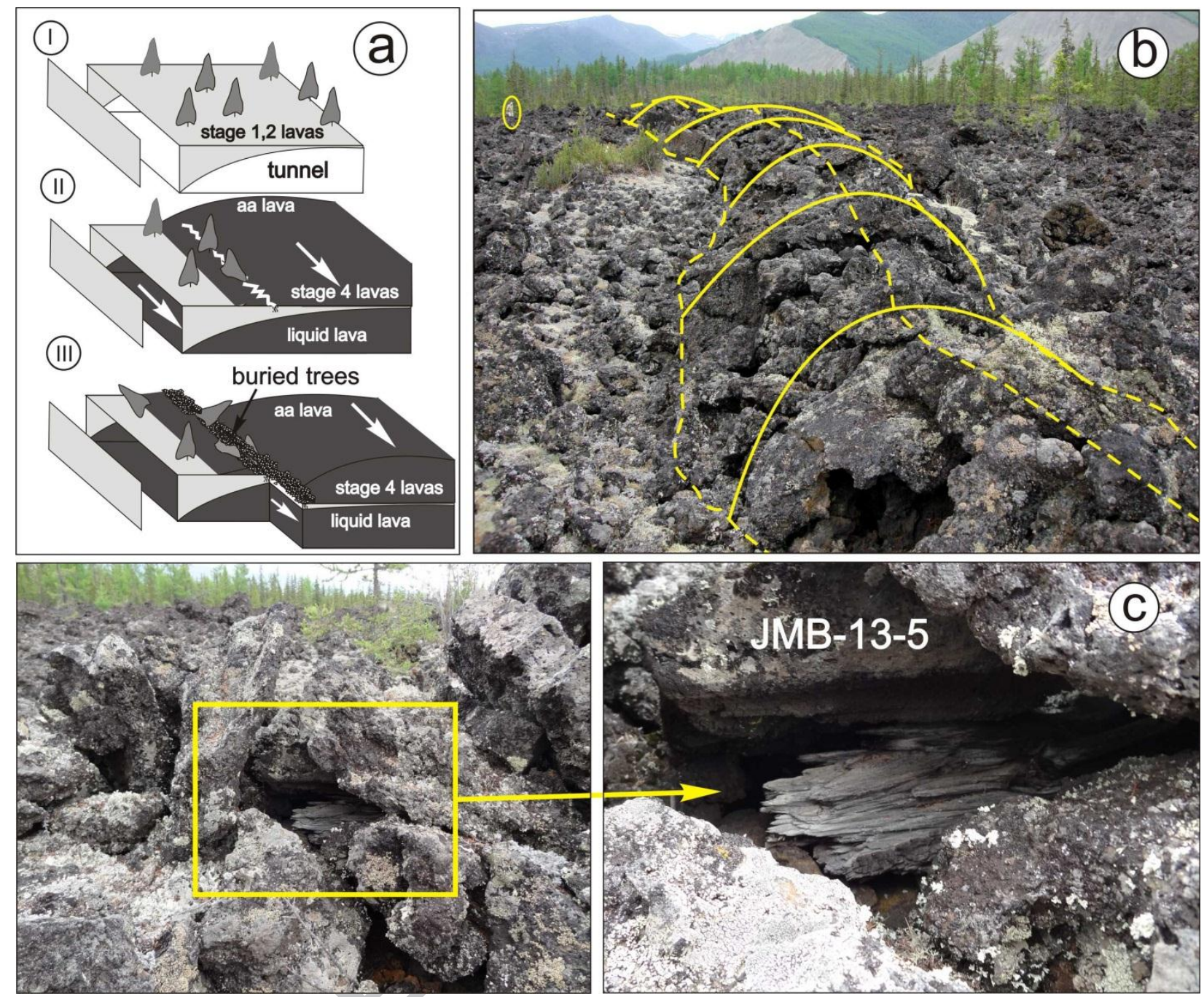

Fig. 7. (a) A model for the formation of lava flows with hummocky-like surfaces and embedded fragments of trees with three stages marked by Latin numbers; (b) field photograph showing hummocks-like structures in the upper basaltic crust where the fragments of trees have been found. A person in the yellow ellipse is for the scale; (c) buried tree fragment (sample JMB-13$5)$.
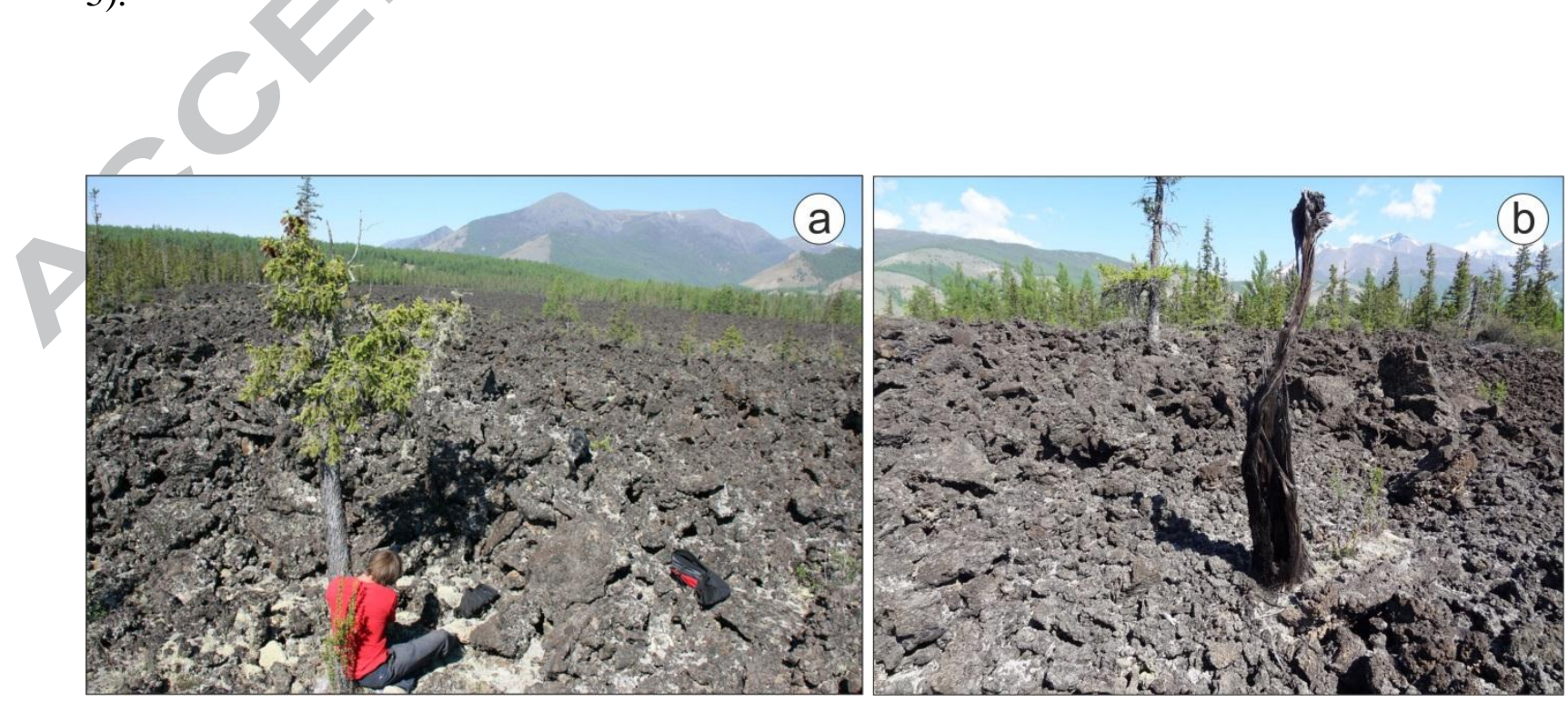

Fig. 8. (a) Live and (b) dead sampled trees from the stage 4 lava. 


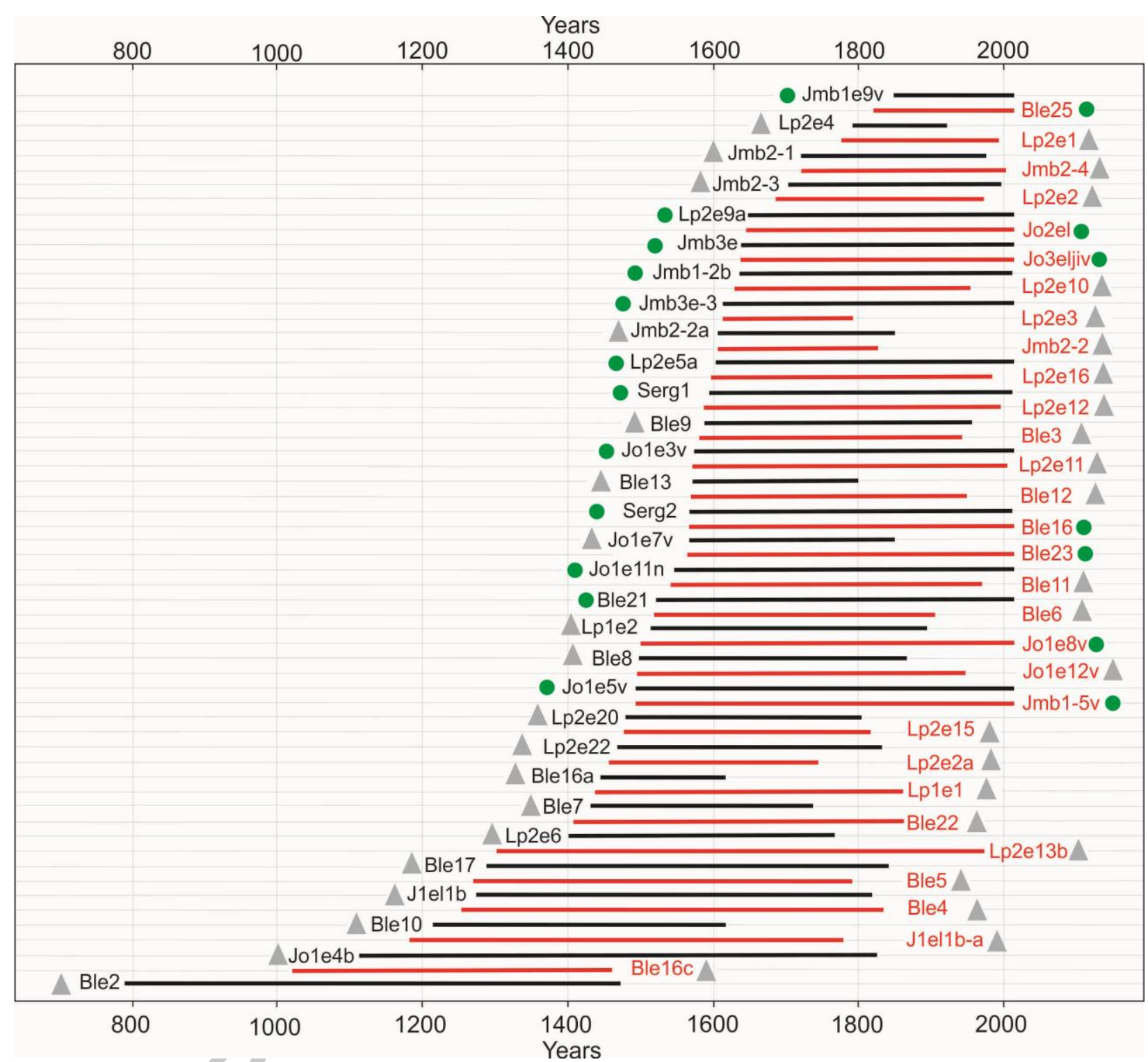

Fig. 9. Distribution on the timeline Std-chronologies of spruce in the study area. The green circle marks living trees, grey triangle - dead trees. 


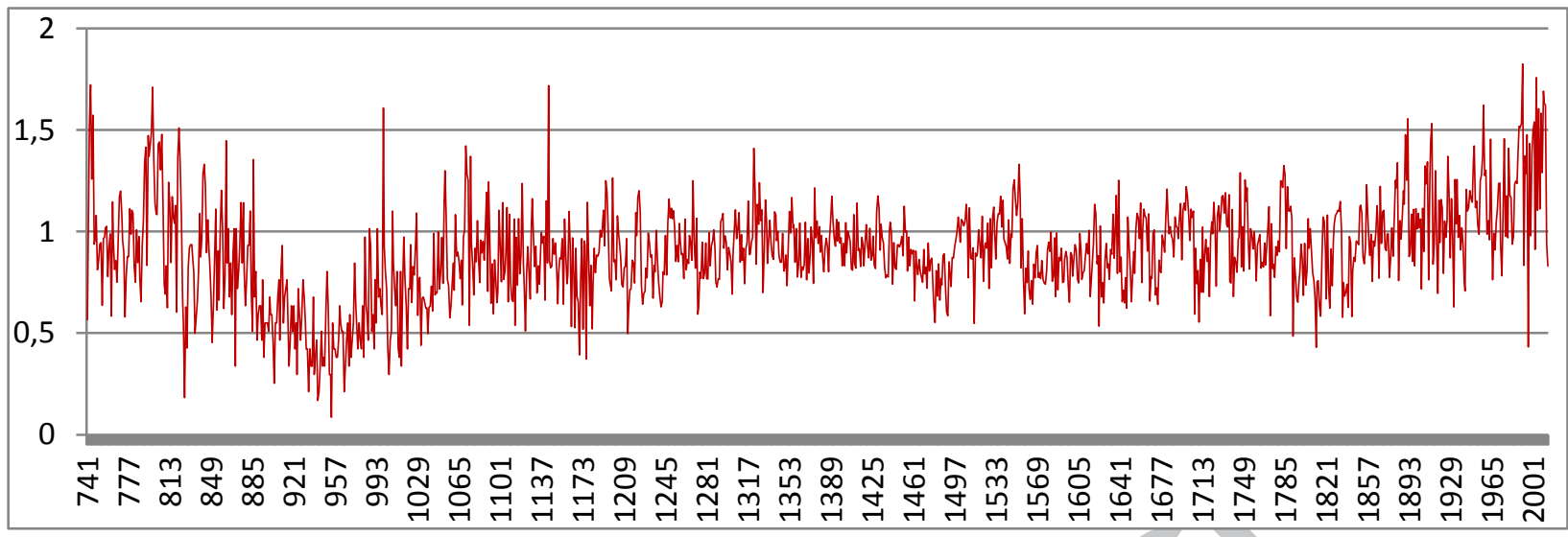

a

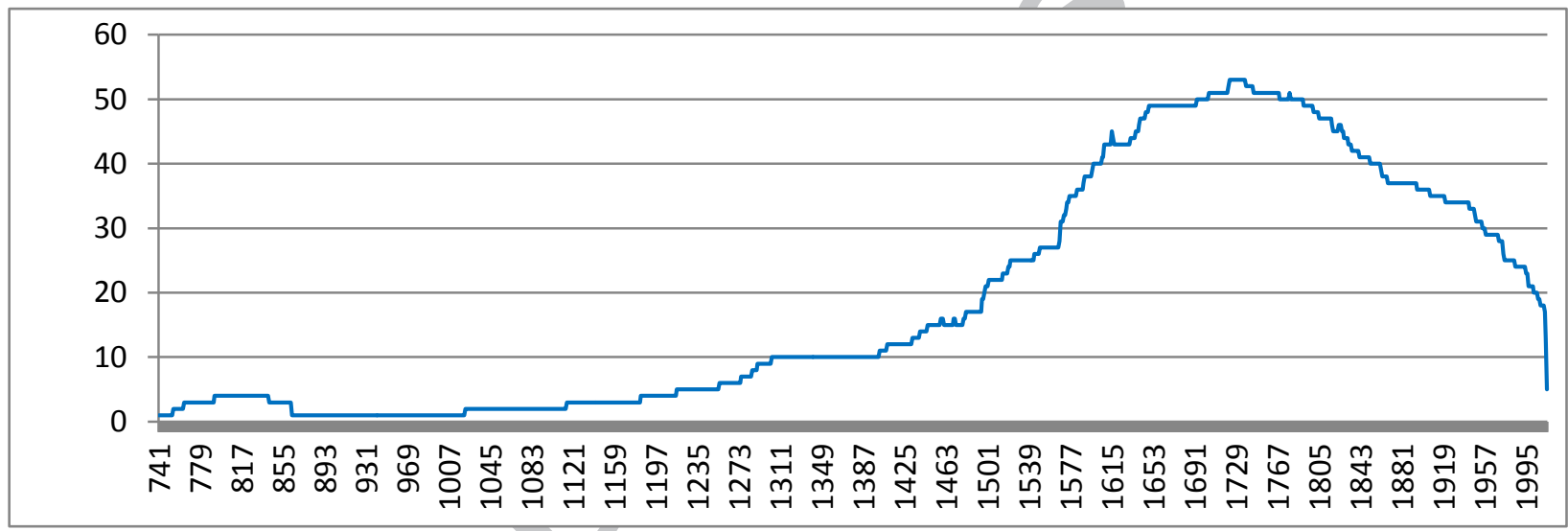

b

Fig. 10. Standardized Pecea obovata chronology (RWI - ring-width index) after fitting a negative exponential curve (a) and sample depth (b). 


\section{ACCEPTED MANUSCRIPT}

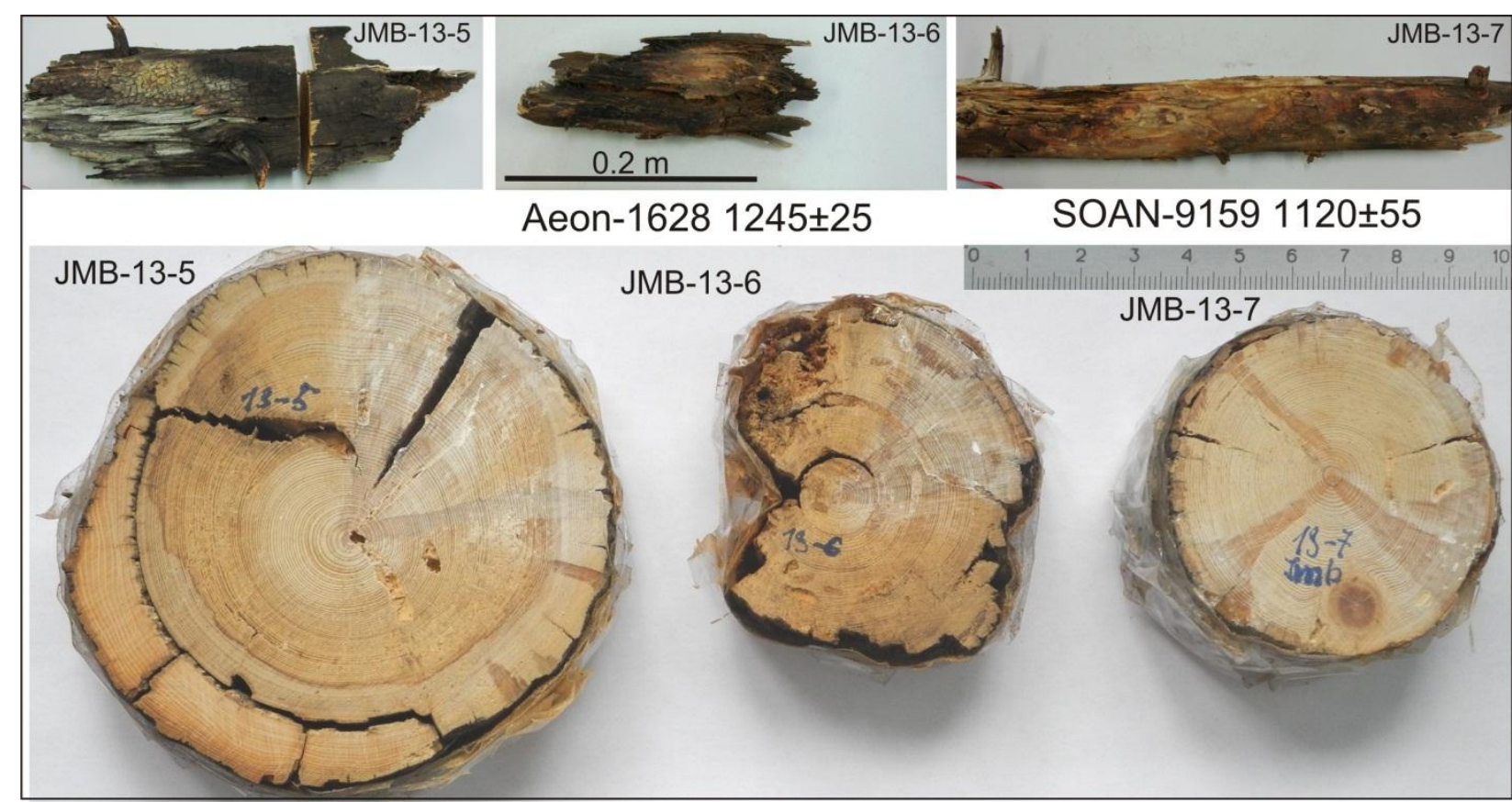

a

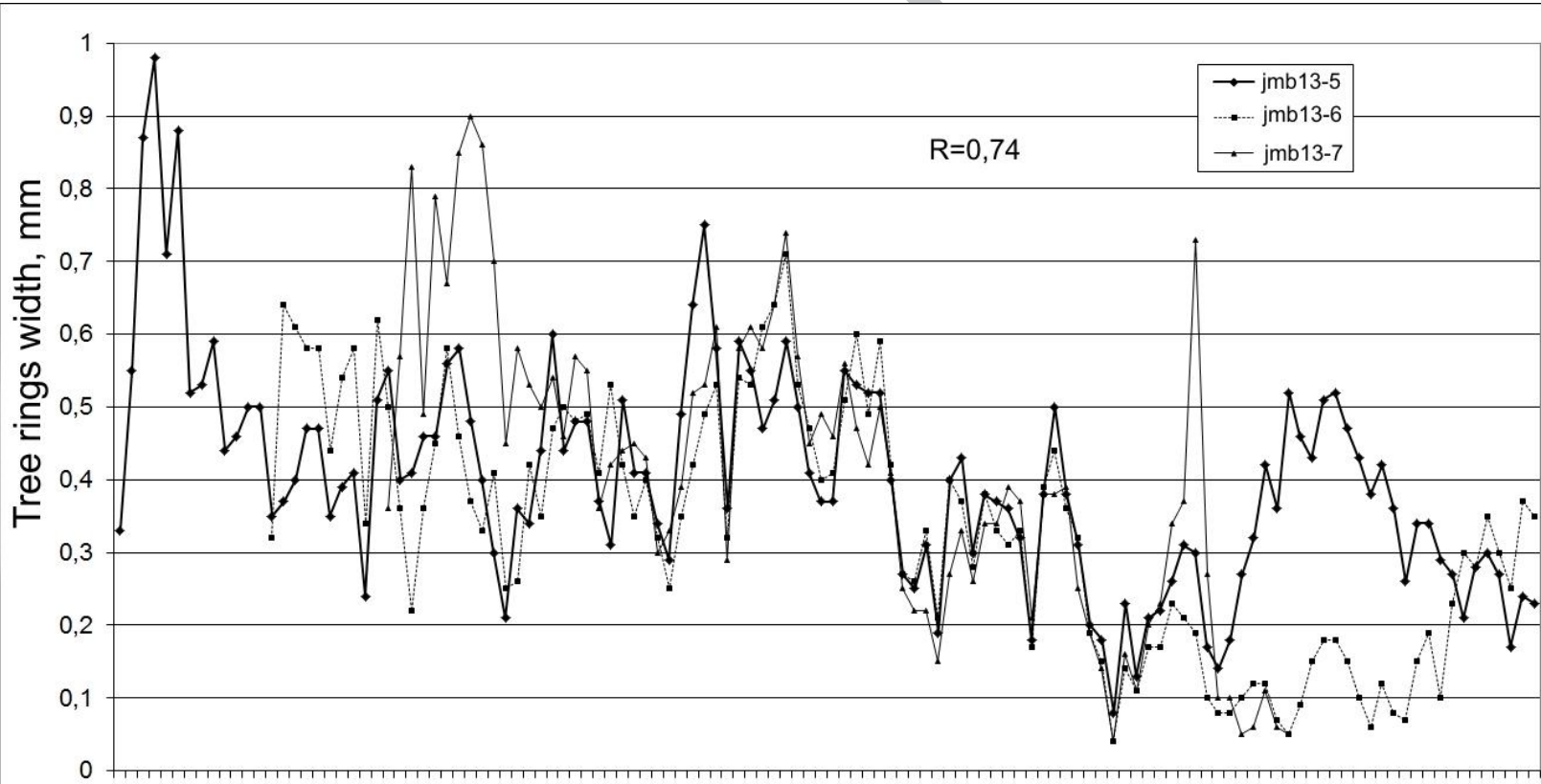

Years

b

Fig. 11. A photograph of the three pieces of one tree, buried in the Jombolok lava field (a). Tree ring chronologies belonging to the same dead buried tree (b). 


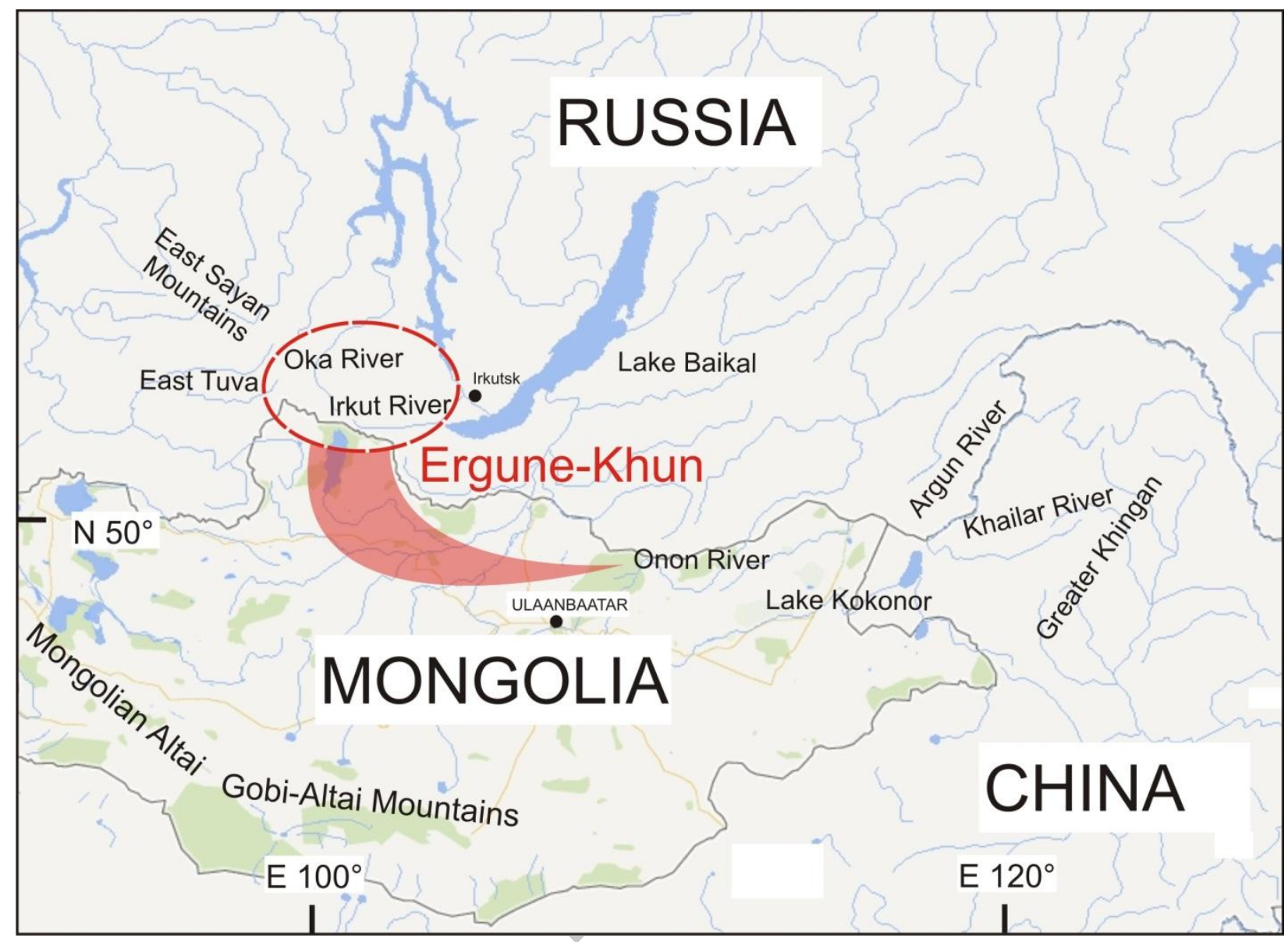

Fig. 12. Ergune-Kun or Erkhuu-Nekhun area (Oka River and Irkut River) in the Estern Sayan Mountains and possible exodus path of Mongol tribes (Chagdurov, 1997, 1998; this study). East Tuva, Mongolian Altai, Gobi-Altai Mountains, Lake Kokonor, Argun River, Khailar River and Greater Khingan are the other regions, which were considered as potential locality of ErguneKun area (Banzarov, 1950; Zoriktuev, 1997; Bilegt, 2007; Abaev, 2011). 


\section{Highlights}

Age Jombolok lava field is $13 \mathrm{ka}$ Jombolok lava field has minimum 4 stage of forming Last stage of volcanic activation was 682-792 A.D. Jombolok eruption triggered exodus pre Chinggis Khaan tribes (778-786 A.D.) 